\title{
Evaluation of Excess Lifetime Cancer Risk Due to Gamma Rays Exposure from Phosphate Fertilisers Used in Saudi Arabia
}

\author{
Fatimh Alshahri \\ Department of Physics, College of Science, Imam Abdulrahman Bin Faisal University, \\ P. O. Box1982, Dammam 31441, Saudi Arabia \\ E-mail: faalshehri@iau.edu.sa
}

Published online: 25 August 2019

To cite this article: Alshahri, F. (2019). Evaluation of excess lifetime cancer risk due to gamma rays exposure from phosphate fertilisers used in Saudi Arabia. J. Phys. Sci., 30(2), 69-80, https://doi.org/10.21315/jps2019.30.2.5

To link to this article: https://doi.org/10.21315/jps2019.30.2.5

\begin{abstract}
Activity concentrations were measured in phosphate fertilisers widely used in Saudi Arabia employing gamma ray spectrometry. The activity concentrations of ${ }^{238} U$, ${ }^{232} \mathrm{Th}$ and ${ }^{40} \mathrm{~K}$ were used to estimate the excess lifetime cancer risk (ELCR). The obtained data show that ${ }^{238} \mathrm{U}$ and ${ }^{40} \mathrm{~K}$ concentrations are higher than the recommended values (35 Bq kg-1 and $400 \mathrm{~Bq} \mathrm{~kg}{ }^{-1}$ for ${ }^{238} \mathrm{U}^{-1}{ }^{40} \mathrm{~K}$, respectively) in most of phosphate fertilisers. The highest value of ${ }^{238} \mathrm{U}$ was $4122 \pm 82 \mathrm{~Bq} \mathrm{~kg}^{-1}$ for diammonium phosphate (DAP) fertiliser. Absorbed dose rate, annual effective dose rate and the ELCR were calculated. The results revealed that the values of outdoor, indoor and total ELCR values were higher than the world averages in all samples except one sample, sample of MAP fertiliser (monoammonium phosphate). The highest value of ELCR ${ }_{\text {tot }}$ was for DAP fertiliser which is 50 times higher than the world average value $\left(1.45 \times 10^{-3}\right)$. Moreover, the results indicated a strong correlation between uranium in phosphate fertilisers and ELCR ${ }_{\text {tot }}$ Based on the obtained results, the direct gamma radiation exposure from phosphate fertilisers is a serious radiological threat to the farmers.
\end{abstract}

Keywords: Phosphate fertilisers, activity concentrations, gamma rays, ELCR, cancer risk

\section{INTRODUCTION}

Natural environmental radioactivity and the associated external exposure due to gamma radiation depend primarily on the geological and geographical conditions, and appear at different levels in the soils of each region in the world. ${ }^{1}$ One of the sources of radioactivity in soils other than those of natural origin is the extensive use of fertilisers rich in phosphates for agricultural purposes. ${ }^{2,3}$ Phosphate fertilisers 
are used widely in the reclamation of farmland and increasing agricultural crops. Moreover, phosphate fertilisers are by far the most widely used for agriculture soil due to its cost-effectiveness and its availability in markets.

Sedimentary phosphate ores can be significantly enriched with naturally occurring radionuclides, uranium $\left({ }^{238} \mathrm{U}\right)$ and the daughter radionuclides that come from the radioactive decay of ${ }^{238} \mathrm{U} .{ }^{4}$ Phosphoric anhydride $\left(\mathrm{P}_{2} \mathrm{O}_{5}\right)$ and potassium oxide $\left(\mathrm{K}_{2} \mathrm{O}\right)$ are important materials used for phosphate fertilisers production. Previous studies have shown that the concentration of uranium and potassium is related to the concentration of $\mathrm{P}_{2} \mathrm{O}_{5}$ and $\mathrm{K}_{2} \mathrm{O}$ in various fertilisers. ${ }^{3,5}$ Phosphate ore is typically extracted from mineral deposits in phosphate rock. The phosphate rocks are used as raw materials in phosphate fertiliser industries, which contain radionuclides of the uranium and thorium natural series. Also, one of the important sources of radioactivity is potassium ${ }^{40} \mathrm{~K}$ which exists in phosphate rocks. ${ }^{6}$

Kingdom of Saudi Arabia is one of the largest producers and exporter of diammonium phosphate (DAP) and compound phosphate fertilisers worldwide. The phosphate fertiliser factories have been provided with phosphate ore from phosphate mine in northern Saudi Arabia. ${ }^{3}$ Before being transported to the factories, the phosphate undergoes the beneficiation process in the plant in order to produce concentrated phosphate ore. Furthermore, several types of imported phosphate fertilisers have been used in agricultural activities. Therefore, concentrations of naturally occurring radionuclides $\left({ }^{238} \mathrm{U},{ }^{232} \mathrm{Th}\right.$ and $\left.{ }^{40} \mathrm{~K}\right)$ in phosphate fertilisers in Saudi Arabia were measured, to evaluate the excess lifetime cancer risk (ELCR) for the population due to gamma rays exposure from phosphate fertilisers.

\section{EXPERIMENTAL}

\subsection{Samples Collection and Preparation}

Seventeen samples of widely used phosphate fertilisers were collected from local markets, Saudi Arabia (Table 1). Four types of phosphate fertilisers were studied: DAP, monoammonium phosphate (MAP), single super phosphate (SSP) and NPK (nitrogen, phosphor and potassium). Concentrations of $\mathrm{P}_{2} \mathrm{O}_{5}$ in fertilisers ranging at $5 \%-61 \%$ is shown in Table 1 . Samples were grinded, dried and packed in the standard size can and tightly sealed and stored for 28 days to acquire secular equilibrium. Reference material was also packed in the same standard size can for efficiency calibration. ${ }^{3}$ 


\subsection{Experimental Setup}

A hyper-pure Germanium detector (HPGe), coaxial type, p-type with relative efficiency of $20 \%$ was used. The resolution (full width at half maximum, FWHM) at the peak $122 \mathrm{keV},{ }^{57} \mathrm{Co}$, is $0.934 \mathrm{keV}$ and at the peak $1332 \mathrm{keV},{ }^{60} \mathrm{Co}$, is $1.79 \mathrm{keV}$. The detector was shielded with lead shield to reduce the background radioactivity. The software Quantum Gold, Version 4.04.00, was used for analysis and evaluation of the gamma-ray spectra. The HPGe was calibrated for efficiency using the reference material RGU-1 from IAEA. The certified activity of uranium is $400 \mathrm{ppm}$ which is equivalent to $4960 \mathrm{~Bq} \mathrm{~kg}^{-1}$. The energy transitions of the ${ }^{226} \mathrm{Ra}$ daughters $\left({ }^{214} \mathrm{~Pb}\right.$ and $\left.{ }^{214} \mathrm{Bi}\right)$ were used to develop the efficiency calibration curve. A fourth-degree polynomial fitting was performed to reach the best $\mathrm{R}^{2}$ value $(\approx 0.983) .{ }^{3}$

Table 1: Description of phosphate fertiliser samples in the present study and their specific activities of ${ }^{238} \mathrm{U},{ }^{232} \mathrm{Th}$ and ${ }^{40} \mathrm{~K}\left(\mathrm{~Bq} \mathrm{~kg}{ }^{-1}\right)$.

\begin{tabular}{|c|c|c|c|c|c|c|c|}
\hline $\begin{array}{l}\text { Sample } \\
\text { no. }\end{array}$ & $\begin{array}{l}\text { Type of } \\
\text { fertiliser }\end{array}$ & Description & Origin & $\mathrm{P}_{2} \mathrm{O}_{5} \%$ & ${ }^{238} \mathrm{U}$ & ${ }^{232} \mathrm{Th}$ & ${ }^{40} \mathrm{~K}$ \\
\hline 1 & DAP & $\begin{array}{l}\text { Granule, } \\
\text { light brown }\end{array}$ & KSA & 46 & $4122 \pm 82$ & $\mathrm{ND}^{*}$ & $131 \pm 11$ \\
\hline 2 & DAP & $\begin{array}{l}\text { Granule, } \\
\text { dark brown }\end{array}$ & KSA & 46 & $3036 \pm 61$ & ND & $74.9 \pm 3.7$ \\
\hline 3 & SSP & $\begin{array}{l}\text { Granule, } \\
\text { dark brown }\end{array}$ & Egypt & 20 & $379 \pm 11$ & $41.2 \pm 3.3$ & $1213 \pm 24$ \\
\hline 4 & MAP & $\begin{array}{l}\text { Cristal, } \\
\text { white }\end{array}$ & Emirate & 61 & $41.4 \pm 1.6$ & $0.711 \pm 0.2$ & $60.0 \pm 3.0$ \\
\hline 5 & NPK & $\begin{array}{l}\text { Powder, } \\
\text { light green }\end{array}$ & KSA & 52 & $57.4 \pm 9.1$ & ND & $1277 \pm 13$ \\
\hline 6 & NPK & $\begin{array}{l}\text { Granule, } \\
\text { pink }\end{array}$ & KSA & 40 & $30.4 \pm 3.6$ & ND & $3519 \pm 21$ \\
\hline 7 & NPK & Granule, red & Germany & 18 & $827 \pm 25$ & $29.1 \pm 5.2$ & $5908 \pm 59$ \\
\hline 8 & NPK & Granule, red & KSA & 5 & $36.9 \pm 7.2$ & ND & $3869 \pm 39$ \\
\hline 9 & NPK & $\begin{array}{l}\text { Powder, } \\
\text { blue }\end{array}$ & KSA & 12 & $436 \pm 8.7$ & ND & $3112 \pm 19$ \\
\hline 10 & NPK & Powder, red & KSA & 18 & $904 \pm 9.0$ & ND & $492 \pm 84$ \\
\hline 11 & NPK & $\begin{array}{l}\text { Powder, } \\
\text { dark pink }\end{array}$ & KSA & 45 & $11.4 \pm 3.3$ & ND & $2137 \pm 17$ \\
\hline 12 & NPK & $\begin{array}{l}\text { Granule, } \\
\text { black }\end{array}$ & China & 10 & $67 \pm 8$ & ND & $2944 \pm 20$ \\
\hline
\end{tabular}


Table 1: (continued)

\begin{tabular}{llllllll}
\hline $\begin{array}{l}\text { Sample } \\
\text { no. }\end{array}$ & $\begin{array}{l}\text { Type of } \\
\text { fertiliser }\end{array}$ & Description & Origin & $\mathrm{P}_{2} \mathrm{O}_{5} \%$ & ${ }^{238} \mathrm{U}$ & ${ }^{232} \mathrm{Th}$ & ${ }^{40} \mathrm{~K}$ \\
\hline 13 & NPK & $\begin{array}{l}\text { Granule, } \\
\text { light brown }\end{array}$ & KSA & 14 & $585 \pm 41$ & $\mathrm{ND}$ & $5029 \pm 43$ \\
14 & NPK & $\begin{array}{l}\text { Granule, } \\
\text { light blue }\end{array}$ & KSA & 12 & $507 \pm 34$ & ND & $6430 \pm 62$ \\
15 & NPK & $\begin{array}{l}\text { Granule, } \\
\text { blue }\end{array}$ & Germany & 12 & $498 \pm 45$ & ND & $3801 \pm 20$ \\
16 & NPK & $\begin{array}{l}\text { Granule, red } \\
17\end{array}$ & KSA & 20 & $1169 \pm 61$ & ND & $1276 \pm 51$ \\
Min & GPK & $\begin{array}{l}\text { Granule, } \\
\text { blue }\end{array}$ & KSA & 14 & $794 \pm 46$ & ND & $5709 \pm 57$ \\
Max & & & & $11.4 \pm 3.3$ & $0.711 \pm 0.2$ & $60.0 \pm 3.0$ \\
\hline
\end{tabular}

Notes: KSA denotes Kingdom of Saudi Arabia; ND denotes not detectable

\subsection{Calculations of Activity Concentrations}

After achieving secular equilibrium and subtraction of the background, the activity concentrations of ${ }^{238} \mathrm{U},{ }^{232} \mathrm{Th}$ and ${ }^{40} \mathrm{~K}$ were calculated. ${ }^{238} \mathrm{U}$ was measured at the gamma lines $63.29 \mathrm{keV}$ and $92.38 \mathrm{keV}$ for ${ }^{234} \mathrm{Th}$. For ${ }^{232} \mathrm{Th}$, the activity concentration was assessed by using energy transition of ${ }^{228} \mathrm{Ac}$ at $93.4 \mathrm{keV}$ and the energy transitions of ${ }^{208} \mathrm{Tl}$ at $583.19 \mathrm{keV}$ and ${ }^{228} \mathrm{Ac}$ at 911.2 . The average values were calculated. In the case of ${ }^{40} \mathrm{~K}$, the specific activity was estimated directly by its gamma line of $1460.75 \mathrm{keV}$.

\section{RESULTS AND DISCUSSION}

\subsection{Activity Concentrations in Phosphate Fertilisers}

The activity concentrations of ${ }^{238} \mathrm{U},{ }^{232} \mathrm{Th}$ and ${ }^{40} \mathrm{~K}$ in phosphate fertilisers were measured as shown in Table 1. The activity concentration of ${ }^{238} \mathrm{U}$ ranges from 11.4 $\pm 3.3 \mathrm{~Bq} \mathrm{~kg}^{-1}$ to $4122 \pm 82 \mathrm{~Bq} \mathrm{~kg}^{-1}$. The activity concentration of ${ }^{232} \mathrm{Th}^{2}$ varies from $0.711 \pm 0.2 \mathrm{~Bq} \mathrm{~kg}^{-1}$ to $41.2 \pm 3.3 \mathrm{~Bq} \mathrm{~kg}^{-1}$. However, 14 samples do not contain ${ }^{232} \mathrm{Th}$ as shown in Table 1. The value of ${ }^{40} \mathrm{~K}$ ranges from $60.0 \pm 3.0 \mathrm{~Bq} \mathrm{~kg}^{-1}$ to $6430 \pm 62$ $\mathrm{Bq} \mathrm{kg}^{-1}$. From these results, it can be observed that the activity concentrations of uranium in 15 phosphate fertiliser samples are higher than permissible limit in soil ( $\left.35 \mathrm{~Bq} \mathrm{~kg}^{-1}\right){ }^{7}$ The highest value was $4122 \pm 82 \mathrm{~Bq} \mathrm{~kg}^{-1}$ for DAP with $46 \%$ of $\mathrm{P}_{2} \mathrm{O}_{5}$ which is 114 times higher than the permissible limit. Uranium content in DAP 
sample was higher than the values in the other phosphate fertiliser samples. High concentration of uranium in DAP fertiliser (KSA) may be due to the use of phosphate rocks as raw materials for manufacturing phosphate fertilisers. ${ }^{89}$ Similarly, the activity concentrations of ${ }^{40} \mathrm{~K}$ in all fertiliser samples were higher than the recommended value ( $400 \mathrm{~Bq} \mathrm{~kg}^{-1}$ ), except of DAP and MAP phosphate fertilisers. ${ }^{7}$ The high concentration of potassium may be related to the concentration of $\mathrm{K}_{2} \mathrm{O}^{3}{ }^{3}$ The result indicates that the large use of phosphate fertilisers leads to increase the radioactivity of soil, especially for DAP fertiliser. The elevated levels of ${ }^{238} \mathrm{U}$ may due to wet phosphate processing where phosphate ore is firstly attacked by sulfuric acid to produce the phosphoric acid where uranium will be mainly concentrated in the phosphoric acid, while radium, thorium and other insoluble radionuclides will be precipitated as sulphate salts and concentrated in the phosphogypsum by product. ${ }^{10}$ In 2000 , Mazzilli et al. found that $90 \%$ of ${ }^{226} \mathrm{Ra}$ and $80 \%$ of ${ }^{232} \mathrm{Th}$ fractionate into phosphogypsum, while ${ }^{238} \mathrm{U}$ was being predominantly incorporated in phosphoric acid. ${ }^{11}$ Uranium and its progenies are usually in secular equilibrium in the different geological formation, while secular equilibrium could be disturbed during chemical treatment of phosphate ore to produce phosphoric acid. ${ }^{10}$

\subsection{ELCR}

There is always a chance of $33 \%$ (or $0.33 \%$ per person) that an individual will be diagnosed with cancer at some stage of life due to normal exposure to natural radioactivity and or a toxic substance. ${ }^{12}$ The Department of Environmental Quality (DEQ) considers a chance of 1 in 100,000 persons. That means $1 \times 10^{-5}$ is allowable limit. ELCR is an additional possibility that a person may develop cancer if that person is exposed to additional cancer-causing materials for a longer time. In order to evaluate the ELCR of phosphate fertilisers, some radiological parameters were calculated (Table 2). The outdoor absorbed dose rate $\left(D_{\text {out }}\right)$ in air $1 \mathrm{~m}$ above the ground surface from the gamma radiation from ${ }^{232} \mathrm{Th},{ }^{238} \mathrm{U}$ and ${ }^{40} \mathrm{~K}$ was calculated. ${ }^{7}$ The conversion factors used to compute the outdoor external dose rate $\left(\mathrm{D}_{\text {out }}\right)$ in air per unit activity concentration in $1 \mathrm{~Bq} \mathrm{~kg}^{-1}$ correspond to $0.604 \mathrm{nGy} \mathrm{h}^{-1}$ for ${ }^{232} \mathrm{Th}, 0.462 \mathrm{nGy} \mathrm{h}^{-1}$ for ${ }^{238} \mathrm{U}$ and $0.0417 \mathrm{nGy} \mathrm{h}^{-1}$ for ${ }^{40} \mathrm{~K}$. Therefore, $\mathrm{D}_{\text {out }}$ could be calculated from the following equation: ${ }^{6,13}$

$$
\mathrm{D}_{\text {out }}\left(\mathrm{nGy} \mathrm{h}^{-1}\right)=0.462 \mathrm{~A}_{\mathrm{U}}+0.604 \mathrm{~A}_{\mathrm{Th}}+0.0417 \mathrm{~A}_{\mathrm{K}}
$$

The indoor gamma ray dose $\left(D_{\text {in }}\right)$ from the above radionuclides was calculated using Equation 2: ${ }^{13}$

$$
\mathrm{D}_{\text {in }}\left(\mathrm{nGy} \mathrm{h}^{-1}\right)=0.92 \mathrm{~A}_{\mathrm{U}}+1.1 \mathrm{~A}_{\mathrm{Th}}+0.081 \mathrm{~A}_{\mathrm{K}}
$$


where $A_{U}, A_{T h}$ and $A_{K}$ are the activity concentrations of ${ }^{238} \mathrm{U},{ }^{232} \mathrm{Th}$ and ${ }^{40} \mathrm{~K}$ $\left(\mathrm{Bq} \mathrm{kg}^{-1}\right)$, respectively.

As shown in Table 2, The outdoor and indoor absorbed dose rates $\left(\mathrm{D}_{\text {out }}\right.$ and $\mathrm{D}_{\text {in }}$ ) in air $1 \mathrm{~m}$ above the ground surface in phosphate fertilisers ranged from 22.1-1910 $\mathrm{nGy} \mathrm{h}^{-1}$ and 43.7-3803 nGy h${ }^{-1}$, respectively. The outdoor and indoor absorbed dose rates in 16 phosphate samples, except MAP, are higher than the world averages for outdoor and indoor exposure due to terrestrial gamma radiation (51 nGy h $\mathrm{h}^{-1}$ and $84 \mathrm{nGy} \mathrm{h}^{-1}$, respectively). ${ }^{7}$ The results indicate the direct connection between the outdoor and indoor absorbed dose rates in air and the specific activity of uranium and potassium, where the greatest part of gamma radiation comes from them.

Outdoor annual effective dose rate, $\mathrm{E}_{\text {out }}\left(\mathrm{mSv}^{-1}\right)$, received by the population is calculated using the following equation:,

$\mathrm{E}_{\text {out }}\left(\mathrm{mSv} \mathrm{y}^{-1}\right)=\mathrm{D}_{\text {out }}\left(\mathrm{nGy} \mathrm{h}^{-1}\right) \times 8760\left(\mathrm{~h} \mathrm{y}^{-1}\right) \times 0.2 \times 0.7\left(\mathrm{~Sv} \mathrm{~Gy}{ }^{-1}\right) \times 10^{-6}$

where,

$\mathrm{D}_{\text {out }}=$ the outdoor absorbed dose rate in air $\left(\mathrm{nGy} \mathrm{h}^{-1}\right)$;

$8760=$ the time for one year $(\mathrm{h})$;

$0.7=$ the conversion factor $\left(\mathrm{Sv} \mathrm{Gy}{ }^{-1}\right)$, which converts the absorbed dose rate in air to human effective dose; and

$0.2=$ the outdoor occupancy factor. $^{7}$

Outdoor annual effective dose rate, $\mathrm{E}_{\text {out }}$, ranged at $0.03-2.34 \mathrm{mSv} \mathrm{y}{ }^{-1}$. It can be observed that the outdoor annual effective dose rate for all samples is higher than the world average value from the outdoor exposure $\left(0.07 \mathrm{mSv} \mathrm{y}^{-1}\right) ., 3$

Similarly, the indoor annual effective dose rate in air was calculated using the formula as follows: ${ }^{3,7}$

$\mathrm{E}_{\text {in }}\left(\mathrm{mSv}^{-1}\right)=\mathrm{D}_{\text {in }}\left(\mathrm{nGy} \mathrm{h}^{-1}\right) \times 8760\left(\mathrm{~h} \mathrm{y}^{-1}\right) \times 0.7\left(\mathrm{~Sv} \mathrm{~Gy}^{-1}\right) \times 10^{-6} \times 0.8$

where,

$\mathrm{D}_{\text {in }}=$ the indoor gamma ray dose;

$0.8=$ the indoor occupancy factor; 
$0.7 \times 10^{-6}=$ the conversion factor from absorbed dose rate in air to effective dose received by the person; and

$8760=$ the time per year $(h)$.

The annual effective dose rate for indoor ranged from $0.21 \mathrm{mSv}^{-1}$ to $18.7 \mathrm{mSv}^{-1}$. The result indicates that the values of indoor annual effective dose rate for all samples, except MAP fertiliser, were higher than the world average of $0.41 \mathrm{mSv} \mathrm{y}^{-1}$ from indoor exposure. ${ }^{7}$

The highest values of $\mathrm{E}_{\text {out }}$ and $\mathrm{E}_{\text {in }}$ are $1910 \mathrm{mSv} \mathrm{y}^{-1}$ and $18.7 \mathrm{mSv}^{-1}$, respectively, in Sample 1 for DAP phosphate fertiliser. Therefore, the agricultural uses of DAP fertilisers could lead to significant radiation exposure. The annual effective dose rate for outdoor and indoor exposure must be less than $0,07 \mathrm{mSv} \mathrm{y}^{-1}$ and $0.41 \mathrm{mSv} \mathrm{y}^{-1}$, respectively, to keep the radiation hazard insignificant.

The ELCR was calculated to estimate the probability of cancer incidence in a population of individuals. The indoor and outdoor ELCR were calculated using the following equations: ${ }^{12,14}$

$$
\begin{aligned}
& \mathrm{ELCR}_{\text {out }}=\mathrm{E}_{\text {out }}\left(\mathrm{mSv} \mathrm{y}^{-1}\right) \times \mathrm{DL}(\mathrm{y}) \times \mathrm{RF}\left(\mathrm{Sv}^{-1}\right) \\
& \mathrm{ELCR}_{\text {in }}=\mathrm{E}_{\text {in }}\left(\mathrm{mSv} \mathrm{y}^{-1}\right) \times \mathrm{DL}(\mathrm{y}) \times \mathrm{RF}\left(\mathrm{Sv}^{-1}\right)
\end{aligned}
$$

where $\mathrm{E}_{\text {in }}, \mathrm{E}_{\text {out }}, \mathrm{DL}$ and RF are indoor and outdoor annual effective dose, duration of life $(70 \mathrm{y})$ and risk factor, 0.05 , for the public, respectively. ${ }^{15}$

From Table 2, the calculated ELCR ${ }_{\text {out }}$ ranged from $0.09 \times 10^{-3}$ to $8.20 \times 10^{-3}$ for outdoor exposure. These values, except the value for MAP, were higher than the worldwide recommended value of $0.29 \times 10^{-3} .^{7}$ The highest value is $8.20 \times$ $10^{-3}$ for DAP fertiliser which is greater than the world average value. The indoor $\mathrm{ELCR}_{\text {in }}$ was calculated to estimate the total ELCR. The indoor ELCR $\mathrm{in}_{\mathrm{in}}$ varied from $0.75 \times 10^{-3}$ to $65.3 \times 10^{-3}$. The $\mathrm{ELCR}_{\text {tot }}$ total for all samples was computed as

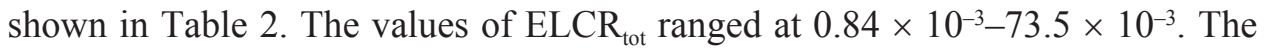
$\mathrm{ELCR}_{\text {tot }}$ total for all samples, expect MAP, are greater than the word average value $1.45 \times 10^{-3} .{ }^{16}$ The highest value was in DAP sample which is 50 times higher than the world average value, $1.45 \times 10^{-3}$. The variations of ELCR can be seen clearly as shown in Figure 1, where the highest value of ELCR was in DAP fertiliser and the lowest value was in MAP fertiliser. 
Table 2: ELCR, absorbed dose rate (D) and annual effective dose (E) for phosphate fertiliser samples.

\begin{tabular}{|c|c|c|c|c|c|c|c|c|}
\hline $\begin{array}{l}\text { Sample } \\
\text { no. }\end{array}$ & Type & $\begin{array}{l}\mathrm{D}_{\text {out }} \\
\left(\mathrm{nGy} \mathrm{h}^{-1}\right)\end{array}$ & $\begin{array}{l}\mathrm{D}_{\text {in }} \\
\left(\mathrm{nGy} \mathrm{h}^{-1}\right)\end{array}$ & $\begin{array}{l}\mathrm{E}_{\text {out }} \\
\left(\mathrm{mSv} \mathrm{y}^{-1}\right)\end{array}$ & $\begin{array}{l}\mathrm{E}_{\mathrm{in}} \\
\left(\mathrm{mSv} \mathrm{y}^{-1}\right)\end{array}$ & $\begin{array}{l}\mathrm{ELCR}_{\text {out }} \\
\times 10^{-3}\end{array}$ & $\begin{array}{l}\mathrm{ELCR}_{\text {in }} \\
\times 10^{-3}\end{array}$ & $\begin{array}{l}\mathrm{ELCR}_{\text {to }} \\
\times 10^{-3}\end{array}$ \\
\hline 1 & DAP & 1910 & 3803 & 2.34 & 18.7 & 8.20 & 65.3 & 73.5 \\
\hline 2 & DAP & 1406 & 2799 & 1.72 & 13.7 & 6.03 & 48.1 & 54.1 \\
\hline 3 & SSP & 251 & 492 & 0.31 & 2.41 & 1.08 & 8.45 & 9.53 \\
\hline 4 & MAP & 22.1 & 43.7 & 0.03 & 0.21 & 0.09 & 0.75 & 0.84 \\
\hline 5 & NPK & 79.8 & 156 & 0.10 & 0.77 & 0.34 & 2.68 & 3.02 \\
\hline 6 & NPK & 161 & 313 & 0.20 & 1.54 & 0.69 & 5.37 & 6.06 \\
\hline 7 & NPK & 628 & 1239 & 0.77 & 6.08 & 2.70 & 21.3 & 24.0 \\
\hline 8 & NPK & 178 & 347 & 0.22 & 1.70 & 0.77 & 5.96 & 6.73 \\
\hline 9 & NPK & 331 & 653 & 0.41 & 3.20 & 1.42 & 11.2 & 12.6 \\
\hline 10 & NPK & 438 & 872 & 0.54 & 4.28 & 1.88 & 15.0 & 16.8 \\
\hline 11 & NPK & 94.4 & 184 & 0.12 & 0.90 & 0.41 & 3.15 & 3.56 \\
\hline 12 & NPK & 154 & 300 & 0.19 & 1.47 & 0.66 & 5.15 & 5.81 \\
\hline 13 & NPK & 480 & 946 & 0.59 & 4.64 & 2.06 & 16.2 & 18.3 \\
\hline 14 & NPK & 502 & 987 & 0.62 & 4.84 & 2.16 & 17.0 & 19.1 \\
\hline 15 & NPK & 389 & 766 & 0.48 & 3.76 & 1.67 & 13.1 & 14.8 \\
\hline 16 & NPK & 593 & 1179 & 0.73 & 5.78 & 2.55 & 20.2 & 22.8 \\
\hline 17 & NPK & 605 & 1193 & 0.74 & 5.85 & 2.60 & 20.5 & 23.1 \\
\hline Min & & 22.1 & 43.7 & 0.03 & 0.21 & 0.09 & 0.75 & 0.84 \\
\hline Max & & 1910 & 3803 & 2.34 & 18.7 & 8.20 & 65.3 & 73.5 \\
\hline $\begin{array}{l}\text { World } \\
\text { average } \\
\text { values. }^{7,16}\end{array}$ & & 59 & 84 & 0.07 & 0.41 & 0.29 & 1.16 & 1.45 \\
\hline
\end{tabular}




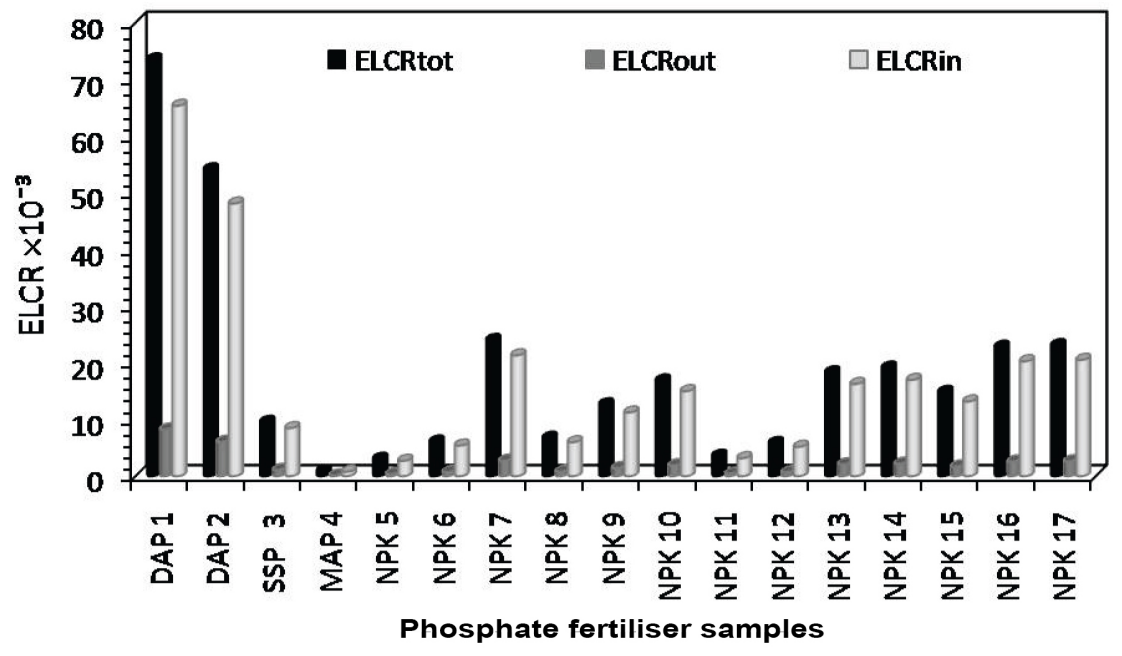

Figure 1: Variations of ELCR in phosphate fertiliser samples.

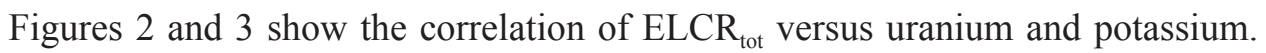
A strong correlation has been observed between $\mathrm{ELCR}_{\text {tot }}$ and uranium with a correlation coefficient of $\mathrm{R}=0.973$ (Figure 2). The correlation of $\mathrm{ELCR}_{\mathrm{tot}}$ versus potassium shows a poor positive correlation with a correlation coefficient of $\mathrm{R}=0.051$. This result revealed that the high values of the excess lifetime cancer risk are attributed to elevated levels of uranium in the analysed phosphate fertiliser samples.

The results indicate that the excessive use of phosphate fertilisers in agriculture soil can lead to increase the radiation risk for public, especially for DAP. Further, the obtained values of absorbed dose rate, annual effective dose rate and the excess lifetime cancer risk in phosphate fertilisers show that the agricultural uses of phosphate fertilisers could lead to increase the probability of cancer incidence in a population of individuals, with the exception of MAP fertiliser. 


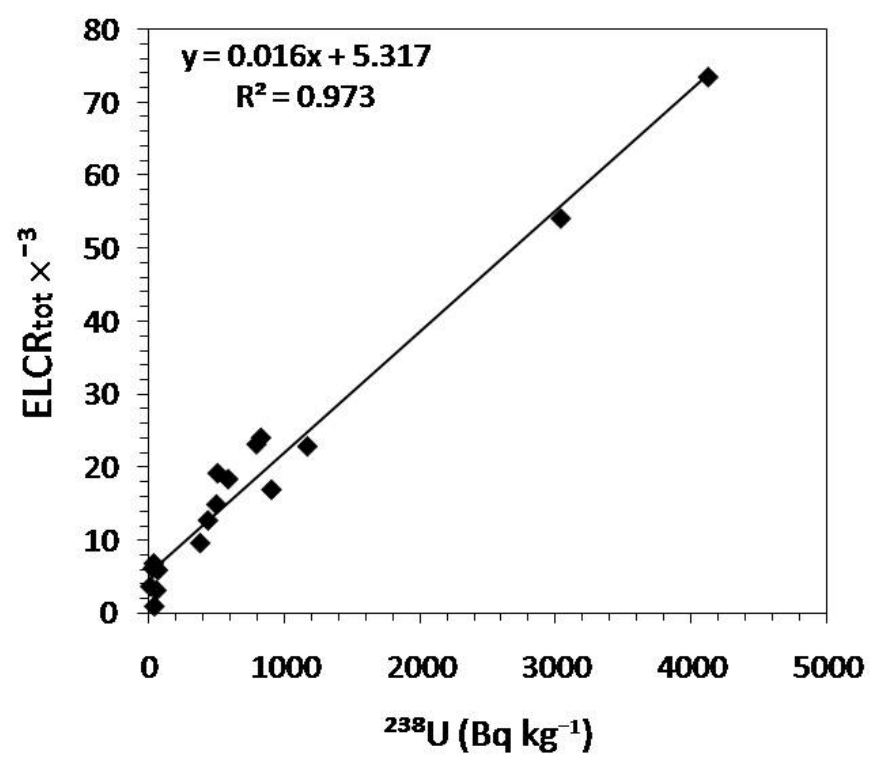

Figure 2: Correlation between uranium concentration and $\mathrm{ELCR}_{\mathrm{tot}}$.

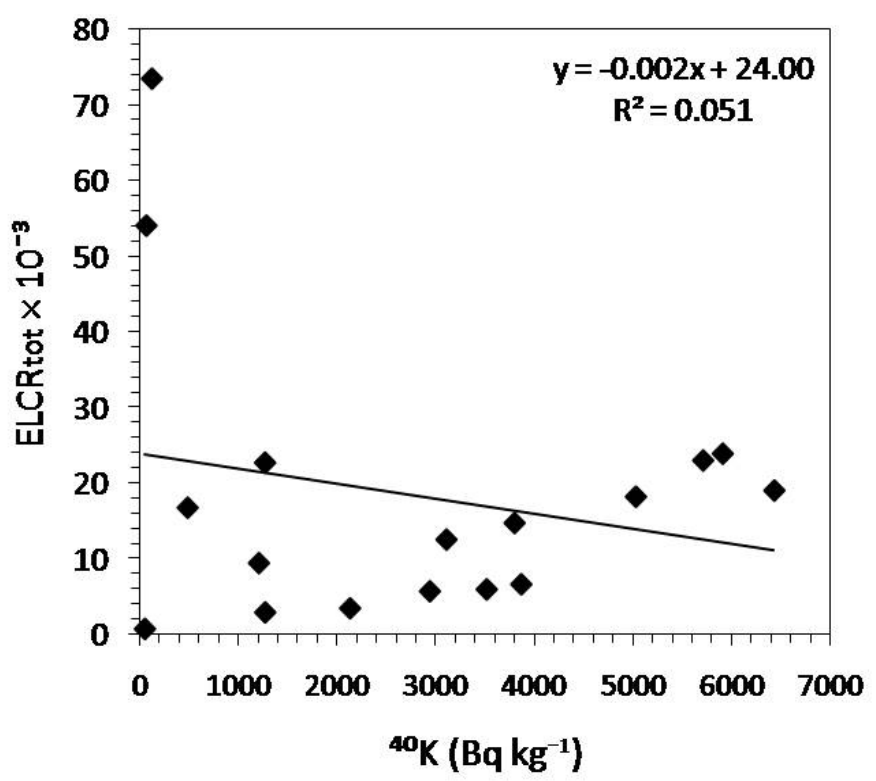

Figure 3: Correlation between potassium concentration and $\mathrm{ELCR}_{\mathrm{tot}}$ in phosphate fertilisers. 


\section{CONCLUSION}

The activity concentrations of ${ }^{238} \mathrm{U},{ }^{232} \mathrm{Th}$ and ${ }^{40} \mathrm{~K}$ in local and imported phosphate fertiliser samples were measured using gamma ray spectrometry technique. The data show that the activity concentrations of ${ }^{238} \mathrm{U}$ in 15 phosphate samples were higher than the world average value $\left(35 \mathrm{~Bq} \mathrm{~kg}^{-1}\right)$, while ${ }^{40} \mathrm{~K}$ activity was higher than the world average value ( $400 \mathrm{~Bq} \mathrm{~kg}^{-1}$ ) in all samples except two samples (DAP and MAP fertilisers). However, the activity concentrations of ${ }^{232} \mathrm{Th}$ were found to be lower than the recommended value $\left(30 \mathrm{~Bq} \mathrm{~kg}^{-1}\right)$ in all phosphate samples. The absorbed dose rate and annual effective dose rate were calculated to evaluate the ELCR for the analysed phosphate fertiliser samples. The outdoor, indoor and ELCR values were higher than the world average values. This result reveals that the direct exposure to the phosphate fertilisers may increase the probability of developing cancer for farmers, especially for DAP fertilisers due to the elevated levels of uranium. Moreover, a strong correlation has been observed between ELCR and uranium. Based on this study, the current data indicate to the need of new rules to improve and develop the regulations that can control the import and production of phosphate fertilisers in Saudi Arabia.

\section{ACKNOWLEDGEMENTS}

The author would like to thank Ms. Ameena Alahmari from the Research Unit, Imam Abdulrahman Bin Faisal University, Saudi Arabia, for helping in gamma-ray spectrometry measurements. Great thanks are extended to Dr. Hanadi Baghdadi, director of Research Unit, Imam Abdulrahman Bin Faisal University, for her support and assistance during this study.

\section{REFERENCES}

1. Diab, H. M. et al. (2008). Evaluation of natural radioactivity in a cultivated area around a fertilizer factory. J. Nucl. Rad. Phys., 3(1), 53-62.

2. Abbady, A. et al. (2008). Gamma-ray measurements of natural radioactivity in cultivated and reclaimed soil, Upper Egypt. Paper presented at the International Conference on Radioecology and Environmental Radioactivity, 15-20 June, Bergen, Norway, 68-71.

3. Alshahri, F. \& Alqahtani, M. (2015). Chemical fertilizers as a source of ${ }^{238} \mathrm{U},{ }^{40} \mathrm{~K}$, ${ }^{226} \mathrm{Ra},{ }^{222} \mathrm{Rn}$ and trace metal pollutant of the environment in Saudi Arabia. Environ. Sci. Pollut. Res., 22(11), 8339-8348.

4. Hamdy, A. et al. (2007). Natural radioactivity in the cultivated land around a fertilizer factory. Paper presented at the Second All African IRPA Regional Radiation Protection Congress, 22-26 April, Ismailia, Egypt, 51-56. 
5. Akhtar, N. et al. (2005). Natural environmental radioactivity and estimation of radiation exposure from saline soils. Int. J. Environ. Sci. Technol., 1(4), 279-285.

6. Ahmed, N. K. \& El-Arabi, A. G. M. (2005). Natural radioactivity in farm soil and phosphate fertilizer and its environmental implications in Qena governorate, Upper Egypt. J. Environ. Radioact., 84(1), 51-64.

7. United Nations Scientific Committee on the Effects of Atomic Radiation, UNSCEAR. (2000). Sources and effects and risks of ionizing radiation. Report to the general assembly with annex A \& B, Vol. I, 20-141, New York, United Nations.

8. Boukhenfouf, W. \& Boucenna, A. (2011). The radioactivity measurements in soils and fertilizers using gamma spectrometry technique. J. Environ. Radioact., 102(4), 336-339.

9. Alshahri, F. (2014). Measurement of ${ }^{222} \mathrm{Rn}$ concentration and exhalation rate from phosphate rocks using SSBD detector in Saudi Arabia. Arab. J. Sci. Eng., 39(7), 5765-5770.

10. Khater, A. E. M. \& Al-Sewaidan, H. A. (2008). Radiation exposure due to agricultural uses of phosphate fertilizers. Radiat. Meas., 43(8), 1402-1407.

11. Mazzilli, B. et al. (2000). Radiochemical characterization of Brazilian phosphogypsum. J. Environ. Radioact., 49(1), 113-122.

12. Ravisankar, R. et al. (2014). Energy dispersive X-ray fluorescence analysis of ancient potteries from Vellore district Tamilnadu, India with statistical approach. J. Radiat. Res. Appl. Sci., 7(1), 44-54.

13. European Commission. (1999). Radiological protection principles concerning the natural radioactivity of building materials. Brussels: European Commission.

14. Kolo, M. T. et al. (2015). Evaluation of radiological risks due to natural radioactivity around Lynas Advanced Material Plant environment, Kuantan, Pahang, Malaysia. Environ. Sci. Pollut. Res., 22(17), 13127-13136.

15. Taskin, H. et al. (2009). Radionuclide concentrations in soil and lifetime cancer risk due to the gamma radioactivity in Kirklareli, Turkey. J. Environ. Radioact., 100(1), 49-53.

16. Qureshi, A. A. et al. (2014). Evaluation of excessive lifetime cancer risk due to natural radioactivity in the rivers sediments of Northern Pakistan. J. Radiat. Res. Appl. Sci., 7(4), 438-447. 